\title{
Salut pública i control social. La ciència al servei de les institucions.
}

Maria-Antònia Martí i Escayol. (1)

scay@bbs-ce.uab.es

\section{Aproximació a la historiografia del higienisme i la història urbana.}

Segons Mumford, la industrialització suposa un trauma pel vell ordre urbà i social que no té cap mena de resposta urbanística. Pel que fa al segle XIX, però, a finals del segle XX la idea de Mumford ha estat revisada per part d'historiadors com Lavedan, Benevolo ${ }^{2}$ o Chocay. Aquests, han estimulat l'anàlisi de l'urbanisme a la ciutat moderna, tot i que dins d'aquesta etapa la recerca s'ha vist força restringida al segle XIX.

Els historiadors d'època contemporània s'han encarregat de remarcar que malgrat els plantejaments del XVIII, les actuacions polítiques del set-cents sobre l'urbanisme foren força limitades. La bibliografia dels contemporanistes sembla voler remarcar que aquests plantejaments no catalitzen fins el segle XIX, amb l'adveniment de la ciència de l'urbanisme i amb la realització de l'obra arquitectònica paradigmàtica de la filosofia del segle XIX: els eixamples. Aquests, s'entenen com el pas que porta de la ciutat mercantil a la ciutat industrial. Així, doncs, s'entén que els eixamples recollirien la manera de fer dels programaris que advocaven per les actuacions globals del XVIII.

Les revisions de Benevolo o Chocay han revalorat el terme d'urbanisme i han estimulat el seu estudi; fet que ha donat lloc a una important branca de la història: la història urbana.

\footnotetext{
${ }^{1}$ Investigadora del Departament d'Història Moderna i Contemporània de la Universitat Autònoma de Barcelona. DESE en Història Moderna (UAB). DESE en Història Econòmica (UAB-UB). Doctorant en Història de la Ciència (UAB).

${ }^{2}$ Benevolo, L., Orígenes del urbanismo moderno, Celeste ediciones, 1994.
} 
El terme urbanisme fou formulat per primera vegada a la segona meitat del segle XIX per assenyalar l'adveniment d'una nova relació entre l'ésser humà occidental i l'organització de les seves ciutats; relació que era el resultat de la revolució industrial -que suposa una transformació radical de les societats gremials, al formar noves aglomeracions que revolucionen l'organització espacial i que formen la metròpolis capitalista ${ }^{3}$; és a dir, la ciutat basada en la lògica capitalista de l'intercanvi i la plusvàlua.

La història urbana dedicada al segle XIX estudia la dialèctica de les tensions latents a la ciutat i les tipifica segons una dicotomia ideològica en: progresistes-reformistes (higienistes, enginyers, administradors municipals, legisladors d'habitatge) i utopistes-culturalistes (socialistes utòpics, revolucionaris socials). Entre els primers, se situaria des de la regulació de Hausmann i Cerdà ${ }^{4}$ fins al racionalisme de Le Corbusier; entre els segons, des de la tradició fabiana i el socialisme utòpic fins a Geddes i Abercrombie.

Entre aquestes propostes urbanístiques cal destacar la de Cerdà. Aquest, des de 1856 fins a 1867, va treballar en la preparació del text que serà la seva teoria general de la urbanització ${ }^{5}$-el primer tractat modern d'urbanisme-, on el creixement urbà s'observa com un procés continu (urbanització) i el planejament com l'aplicació racional de diferents anàlisis científiques. Entre aquestes solucions científiques remarquem les solucions tècniques de circulació, les prioritats higièniques per a l'allotjament, la subdivisió racional del terreny, l'estadística de les

3 Reason, character, evolution and environment: theory and policy in Victorian social science, c.1860 c.1895, James G. Webster, 1993, Director: Jose F. Harris; The role of the courts in the control of environmental pollution: a llegal and historical analysis, C.A. Gearty, 1987, Director: D.G.T. Williams;An investigation into the perceptions and attitudes to environmental and social conditions affecting the policies of administrative authorities in a part of North London, 1855-75, Billie Connell, 1992, J.Wareing, P.F.Brandon;Some environmental aspects of public health and local government in Keighley, 1850-1900, P.Mawson, 1983, Director: A.J.Taylo;The local economy, the built environment and their effects upon the standards of private and public health in West Hartlepool, 1919-39, Robert A.Wilson;Geographical images of Utah: non-Mormon perceptions of the environment, c. 1545-1857, B.E. Price, 1987, Director: J.F. Davis; Black spot on the Mersey: a study of environment and society in $18^{\text {th }}$ - an $19^{\text {th }}$ - century Liverpool. I.C. Taylor, 1976, Director: R. Lawton

${ }^{4}$ Cerdà, I., Teoría General de la Urbanización. Reforma y ensanche de Barcelona (1867), Barcelona, Instituto de Estudios Fiscales, 1968

${ }^{5}$ Bassols, M., Ildefons Cerdà davant l'ordenació jurídica de l'urbanisme: aportacions i anticipacions. I Jornades Internacionals, Barcelona, Cerdà Urbs i Territori, 1995. 
necessitats socials. Aquests estudis configuren una nova idea de ciutat que respon al nou ordre racional-liberal. Un ordre on els valors exaltats són els de la nova civilització maquinista; on el progrés s'identifica amb l'economia liberal, amb la tècnica i amb la higiene; on la raó s'identifica amb la ciència; i l'ordre, amb la igualtat.

La historiografia de l'època moderna dedicada a l'urbanisme ha remarcat que els programes de reordenament de les ciutats de finals del segle XVIII tenien com a objectiu fer actuacions globals per ordenar l'àrea urbana; uns programes legitimats amb la lògica de la política il-lustrada i amb la lògica de la salut pública.

Quant a la política, amb el procés de formació de l'estat modern, es produí un enfortiment de les idees estatals. Es consolidaren les idees mercantilistes i la filosofia humanista de la il-lustració -que advocaven per l'augment del nombre de persones, i especialment de les persones sanes, com a base d'un estat fort. Una política que dominava en un moment marcat pel deteriorament de les condicions de vida i de treball de les masses proletàries que, procedents de l'èxode rural, s'amuntegaven en els suburbis insalubres i miserables de les ciutats europees.

D'altra banda, a finals del set-cents els documents mèdics són abundants a causa de la institucionalització de l'ensenyament mèdic, l'extensió de la contractació de professionals i el desenvolupament de juntes i comissions de sanitat que esdevingueren permanents. En efecte, des de mitjans del XVIII els estats europeus promogueren campanyes de preservació i millora de la salut dels seus habitants. Aquesta conjuntura generà la multiplicació d'una documentació centrada en l'anàlisi de l'impacte sobre la salut dels elements que configuren la primera industrialització. Sent una documentació que se centrarà especialment en l'estudi de la relació de l'impacte de l'industria sobre la qualitat de l'aire.

Les propostes derivades de les preocupacions dels governs i les suggerencies dels metges, sovint interseccionaran en un mateix objectiu: recuperar l'eficàcia de la mà d'obra productiva, evitar les reticències a les noves tecnologies legitimant-les en el saber mèdic, reduir la conflictivitat social i protegir la salut de la població no treballadora. Així, el concepte de salut pública de finals del XVIII denota el control polític sobre la pràctica mèdica, i es diferencia de 
l'anterior concepte de salut pública que feia referència exclusivament a aconseguir la salut de la gent ${ }^{6}$. A finals del XVIII, doncs, l'impacte de la industria junt amb la sistematització de la medicina possibilita resseguir amb claretat les actuacions del govern sobre el medi.

El control de l'aire en les zones urbanes de les societats il.lustrades.

L'aire com a problema ambiental prent protagonisme entrat el XVIII. Un protagonisme evidenciat per la potenciació de la política de control d'aquest. Un procés paral-lel al viscut en d'altres territoris, tal i com constata la bibliografia mèdica referent a l'època, amb articles ja clàssics com els de Etlin ${ }^{7}$, Jordanova ${ }^{8}$, Pickstone $^{9}$, Pringle, i Saba ${ }^{10}$. Així, la política de control de l'aire farà proliferar la documentació referent als espais urbans de les places, els cementiris ${ }^{11}$, el tractament dels animals morts, l'arquitectura de les cases, l'amplada dels carrers, la neteja de la ciutat, etc.

L'aire com a problema i com a objecte d'anàlisi es potencià arrel els canvis produits a finals del set-cents amb la introducció del carbó mineral i el tintatge. A partir d'aquest moment, el centre dels discursos mèdics girarà entorn la qualitat de l'aire en relació a aquests nous materials emprats.

A Catalunya, a mesura que avança el segle XVIII, la introducció de nous materials i fonts d'energia generarà intensos debats institucionals i publicístics.

\footnotetext{
${ }^{6}$ A Anglaterra, per exemple, és paradigma d'aquesta salut pública amb el Sanitary Movement de finals del XVIII, B. Spector: "Jeremy Bentham, 1748-1832: His influence upon Medical Thougth and Legislation"6.

${ }^{7}$ Etlin, R., "L'air dans l'urbanisme des Lumières", Dix-huitième siècle, 9, 1977, pp. 123-134

8 Jordanova, L., "Policing Public Health in France, 1780-1815", a Ogawa, T., (ed.), Public Health, Tokyo, Tanaguchi Foundation, 1981, pp. 12-32

${ }^{9}$ Pickstone, John V., "Death, dirt, and fever epidemics: rewriting the history of British Public Health" a Ranger, T., i Slack, P., (eds.), Epidemics and Ideas. Essays on the historical perception of pestilence, Nova York, Cambridge University Press, 1992, pp. 125-148

10 Pringle, J. K., Saba, S. J., "Language médical et politique locale: l'urbanisme et la santé à Marseille à la fin de l'Ancien Régime", Annales du Midi, tome 93, №154, 1981, pp. 397-417;

${ }^{11}$ Ramon de Huesca, Nueva instancia a favor de los cementerios contra las preocupaciones del vulgo: tratado en que discurriendo por las epocas mas notables se demuestra que enterrar los muertos en los cementerios fuera de los templos y las poblaciones es conforme á la piedad christiana y necesario a la salud publica, Pamplona, 1792; Francisco Bruno Fernández, Disertacions físico legal de los sitios y parages que se deven destinar para las sepulturas, Madrid, 1783.
} 
Debats suscitats, en certa mesura, pels temors a les possibles conseqüències negatives que aquestes innovacions podrien provocar sobre la salut i pels possibles perjudicis que podia ocasionar sobre els oficis lligats a les fonts d'energia i materials tradicionals. Els problemes ambientals més candents foren els derivats, d'una banda, de les fàbriques d'indianes i, per extensió, de les industries derivades d'aquestes, com la del sabó; i, d'altra banda, de la introducció del carbó mineral com a combustible -que tenia l'objectiu de suplir uns combustibles tradicionals, els vegetals, cada cop més difícils d'aconseguir.

Els dos fenòmens tenen coincidències interpretatives en tres punts:

1. Es palesa el característic lligam entre la política i l'estament mèdic. Un lligam emmarcat en el moviment de la Salut Pública del set-cents, i que es manifesta a través de la continua demanda d'informes als metges sobre la salubritat del carbó mineral i dels productes químics del tintatge. Uns metges situats dins la conjuntura de les concepcions neohipocràtiques i, alhora, dins l'emergència de la química com a ciència -tant de la química terapèutica, com de la química analítica de la combustió i de la composició de l'aire. La demanda política vers aquests metges tindrà com a objectiu aconseguir una resposta mèdica legitimadora de les activitats econòmiques que tracten d'impulsar les institucions.

2. Es constata la ideologia il-lustrada i l'interès econòmic de les institucions per tirar endavant una tecnologia que desperta recel tant dintre de les mateixes institucions com entre els ciutadans. Significativament, els eixos discursius de la documentació favorable al progrés econòmic són -seguint un document referent als conflictes generats per les fàbriques de sabó: "dexar atendida los tres objetos: la salut pública, la comodidad de los habitantes, y el desembarazo y libertat para las fábricas de algodón y lana para que tengan todo el gobierno que es manester darles"12.

${ }^{12}$ AHB, Político, Real y Decretos, 1784, fol. 290 i ss. 
3. En ambdós casos es genera una dialèctica trífida -política, econòmica i social- entre les diferents institucions i economies, i entre aquestes i la societat. D'una banda, s'observa l'actitud diferenciada entre l'Ajuntament, en principi reticent a les innovacions, i l'Audiència, que les impulsa. D'altra banda, s'observa l'actitud reticent dels ciutadans que basen la seva vida en les activitats econòmiques tradicionals, i dels ciutadans que reben els perjudicis de l'aire viciat pel fum del carbó o pels components químics de les industries tèxtils. Així, aquesta multiplicitat de reaccions dialèctiques ens il.lustra l'enfrontament entre els diferents interessos i la seva relació amb el desenvolupament de la tecnologia; constatació que ens permet d'aplicar la primera llei de Kranzberg referent al fet que la tecnologia no és bona ni dolenta, ni és neutral.

\section{L'art de tenyir a la Barcelona de finals del XVIII.}

Amb l'impuls de les tintures, des de principis de la dècada dels 80 , la recerca de l'harmonia entre la salubritat de la ciutat i l'avenç de la industria dominarà, en bona part, la política municipal de Barcelona. Entre les activitats derivades de la fabricació d'indianes, la fabricació del sabó serà un dels elements que generarà un estira-i-arronsa més aferrissat entre les institucions, els fabricants i els veïns.

Quant a les fàbriques d'indianes, han estat molts els historiadors que han interpretat el fet que, a finals del XVIII, la Junta de Sanitat de Barcelona demanés als metges de Sanitat i de l'Acadèmia de Medicina que elaboressin informes referents a l'augment de les morts sobtades esdevingudes a Barcelona ${ }^{13}$. Una demanda que palesa la voluntat de les autoritats civils de reorganitzar la ciutat, per intentar fer-la més sana i salubre. Una voluntat copsada per tota la documentació de l'època amb obres com, per exemple, la de Ponci Cabanach, Prontuario jurídico

\footnotetext{
${ }^{13}$ Carrera i Pujal, p. 98; García Fuertes, G., "El panorama sanitario de Barcelona a finales del siglo XVIII", Actes del ler Congrés d'Història Moderna de Catalunya, 2, 657-665; Gorina, N., "La Academia médico-práctica en la epidemiología barcelonesa del setecientos, 1770-1800", Medicina e Historia, 22, 1-16; Simon i Tarrés, A., Aproximació al pensament demogràfic a Catalunya, Barcelona, Curial, 1995.
} 
y elementos prácticos para exercer el arte de edificar sin agravio del vecino ${ }^{14}$; un manuscrit que fa referència a les normes legals per construir a Barcelona sense perjudicar als veïns. Una obra que tracte temes com les conduccions d'aigua, les xemeneies, els pous, les clavegueres, les latrines, els carrers, les teulades, els cementiris, etc.

El procés entorn la salubritat de les indianes començà amb un informe de 1781 elaborat pel doctor Pere Güell i Pellicer (1712-1791); informe que exposava les causes de les malalties que patien els obrers dels tallers i de les fàbriques de la ciutat ${ }^{15}$. Arran del treball de Güell, es manaren més informes que derivaren en la prohibició, de l'any 1784, d'establir més fàbriques a l'interior de la ciutat.

Tres mesos després, però, la prohibició fou revocada arran de la publicació d'un informe de Masdevall (1740?-1801) ${ }^{16}$-metge d'origen empordanès graduat per la Universitat de Cervera i doctorat a Montpeller, metge de cambra de Carles III i inspector d'epidèmies del Principat de Catalunya-. Un text que és una reacció, que resultarà victoriosa, a l'enfrontament mèdic entorn la salubritat de les indústries de Barcelona ${ }^{17}$.

\section{La contaminació química i la seva legitimació durant la primera industrialització a Barcelona.}

Dins les anàlisis historiogràfiques generades pel text de Masdevall seria útil afegir la legitimació que l'autor fa de la química industrial i de la química mèdica. Una ciència química que també serà el centre dels arguments justificadors del

\footnotetext{
${ }^{14}$ Cabanach, P., Prontuario jurídico y elementos prácticos para exercer el arte de edificar sin agravio del vecino, 1789, AHB, Ms. A-no55.

${ }^{15}$ Güell i Pellicer, P., (1712-1791), Causas de las muertes repentinas y aplopejias, AHMB, Junta de Sanitat, Varia, IX, núm, 5, lletra F.

${ }^{16}$ Dictamen del mismo doctor Don Joseph Masdevall, dado de órden del rey sobre si las fabricas de algodón y lana son perniciosas o no a la salud pública de las ciudades donde estan establecidas, escrit el 1784 i reeditat més tard com a apèndix del llibre del mateix autor: Relación de las epidemias de calenturas pútridas y malignas que en estos últimos años se han padecido en el principado de Cataluña, Madrid, 1786. Agraïm al Doctor Jordi Nadal i Oller la cessió del document.

${ }^{17}$ Memorials conservats a l'Institut Municipal d'Història de Barcelona, Fons de Sanitat, VI. Vol.14, f. 144-233. Reproduits a: Zarzoso, A., Prevenció epidèmica i salut pública a la Barcelona del segle XVIII, Barcelona, treball de recerca, Institut Univ. d'Història J.Vicens i Vives, Universitat Pompeu Fabra, 1994.
} 
discurs mèdic i institucional que promou la introducció del carbó mineral com a combustible per les fàbriques i pel consum quotidià. Així, en els aspectes referents a la salut, més que no pas en els aspectes pròpiament econòmics, serà allà on amb més força les institucions donaran per bona $i$, fins $i$ tot, per necessaria la conveniència de l'ús del carbó mineral i de la química aplicada en la indústria.

Una legitimació a través de la química clau d'una banda, per l'economia industrial de la Barcelona de finals del XVIII i, d'altra banda, clau per la medicina de l'època.

En efecte, en la documentació del darrer quart del set-cents s'evidencia com la Junta de Comerç considera cabdal la col-laboració amb la Real Acadèmia de Ciències i Arts per aconseguir millorar el tintatge a través de les regles de la química. Pel que fa a la legitimació de la química a través de la medicina, només cal citar l'obra del prestigiós metge Francesc Carbonell (Barcelona 1758-1837) ${ }^{18}$. Aquest, l'any 1796, declarà que pel farmacèutic són bàsics i imprescindibles adquirir coneixements i exercir l'estudi i la pràctica de la química. Argumentant que així ho recomanen autors com Baume i Laugier, dos dels representants cabdals del grup de metges que estimulava la terapèutica química aplicada a la medicina.

En el document de Masdevall s'evidencia un coneixement perfecte d'allò que la historiografia ha qualificat com a "diferents cultures de la química"19. Un coneixement que Masdevall empra per justificar els seus arguments mèdics i econòmics; puix que la terapèutica química serà emprada per Masdevall com l'argument legitimador de la química industrial. Així, doncs, el text de Masdevall ${ }^{20}$

\footnotetext{
${ }^{18}$ Carbonell, F., Elementos de farmacia fundados en los principios de la química moderna. Su autor el Doctor don Francisco Carbonell, catedrático de química en Barcelona, farmacéutico boticario colegial de aquella ciudad, y del Real Colegio de Farmacia de Madrid, miembro titular de la sociedad académica de ciencias de Paris, académico numerario y director de químca de la Real Academia de Ciencias naturales y artes de Barcelona, socio residente de la Real Academia de medicina Práctica de la mismo, socio íntimo de la Real Academia Médico-Práctica de Cartagena, y corresponsal de varias Sociedcades y cuerpos literarios. Tercera edición corregida y aumentada. 1805. Primera edició de 1796.

${ }^{19}$ Holmes, F. L., "Concluding Remarks: Beyond the Boundaries, a B.Bensaude-Vincent, Lavoisier in European Context. Negotiating a New Language for Chemistry, Canton, 1995

${ }^{20}$ López Piñero indica com són tres els metge espanyols que abans d'acabar el segle XVIII s'ocupen de qüestions de medicina indústrial: Francisco López de Arévalo, Josep Masdevall i Ambrosio Maria Ximenez de Lorite, Medicina y sociedad en la España del siglo XIX, Madrid, 1964, p. 111
} 
utilitza arguments provinents dels seus coneixements en química mèdica per justificar que no només no existeix perill en l'ús de la química industrial sinó que, al contrari, aquest ús és beneficiós per la salut. En efecte, l'autor, lluny de criticar la química, assegura que aquesta enforteix ${ }^{21} \mathrm{i}$, fins $\mathrm{i}$ tot, protegeix de les malalties. Argumentació que el porta a afirmar que els treballadors de les fàbriques de tint de Barcelona són els més sans de l'estat ${ }^{22}$.

La definició de Chaptal d'aquests practicants fou el de "metge-químic"; concepte que definia aquells que tenien una formació relacionada amb la salut i, alhora, s'interessaven per la química moderna en la seva utilitat mèdica, industrial i agrícola. Així, el "metge-químic" exercia una tasca trífida amb elements de medicina, química i industria.

Cal recordar, d'una banda, que Masdevall va ser educat a l'estranger i palesà sempre gran interès per les ciències de la naturalesa $\mathrm{i}$, molt especialment, per la química; d'altra banda, el text està emmarcat en un moment d'emergència de noves institucions científiques i d'un creixent suport social als avenços científics més innovadors, com la química, que es produeix com a resultat de l'interès en el progrés material i en la prosperitat.

Així, els arguments utilitzats per Masdevall a l'hora de legitimar la salubritat dels components químics emprats en la indústria, estan fonamentats en la pràctica mèdica que amb Paracels obrí una escletxa en la farmacologia tradicional. En efecte, la spagirica o principis químics de Paracels ${ }^{23}$, arrencà definitivament de mans dels alquimistes la química per posar-la en mans dels metges, cercant en la química la capacitat de curar. Concepció que propugnava una terapèutica basada en una concepció quimicista del cos humà, i que defensava els remeis químics en el tractament de les malalties. Tal i com exposa Masdevall:

\footnotetext{
${ }^{21}$ Saladrich, J., ens parla d'informes com els de M.Ure segons el qual el treball a les fabriques, lluny de provocar malalties, enfortia als operaris, p. 237-243, J.M. Salarich, "Higiene del tejedor", Condiciones de vida y trabajo obrero en la España de mediados del siglo XIX, Ed. Anthropos, Barcelona, 1984

22 Masdevall, J., Dictamen...op.cit., p. 17

${ }^{23}$ Sobre Paracels, veure: Pagel, W., Debus, A., "Paracelso y los paraceltistas", a Laín Entralgo, P. (ed.), Historia universal de la medicina, 7vols. Barcelona, Salvat, 1972-1975; Debus, A., El hombres y la naturaleza en el renacimiento; Brock, W.H., Historia de la química, Madrid, Alianza, 1996.
} 
"Aunque todos los Autores de Medicina convienen unanimamente que el aceyte de vitriolo, el agua fuerte ${ }^{24}$ y todas las especies de arsénicos corroen nuestras entrañas tomados solos y en cierta cantidad, y el que el sal saturno tomado interiormente ocasiona muchas veces diferentes enfermedades en los nervios, nos dicen los mas, que con todas las referidas sustancias se forman varias combinaciones y remedios compuestos, que tomados interiormente nos curan de varias enfermedades agudas, crónicas y muy rebeldes. No dudan diferentes ( $y$ son Autores de los mas clásicos) en prescribir el aceyte de vitriolo, mezclado en agua para curar las viruela malignas (...), to mismo se hace con el agua fuerte (...)No se necessita mucha Medicina ni mucha inteligencia para comprehender que son muchas mas las partecillas de estos ingredientes que entran en nuestros cuerpos, y que se mezclan con nuestra sangre por medio de dichas bebidas, que las que pueden mezclárseles de las que eshalan los sobredichos tintes: de lo que se ve claro que estos de ningún modo pueden dañar a la humana naturaleza"25“Igualmente muchos respetables Autores hacen tomar en pequeñas cantidades, en sustancia y sin mezcla de correctivo, el azúcar de plomo ó sal de saturno en varias enfermedades, $y$ esto por muchos dias seguidos $(\ldots)^{\prime \prime 26}$

En resum, si, d'una banda, podem afirmar que el text de Masdevall és una defensa de la indústria com a font de riquesa del país i d'augment del benestar de la població ${ }^{27}$. D'altra banda, també podem dir que és una defensa de la química com a ciència aplicada a la medicina i a la industria.

\footnotetext{
${ }^{24}$ Cal veure les discussions de l'època entorn els mètodes de purificació de l'aigua fort o àcid nítric. "Observaciones sobre el influxo de la luz solar, especialmente en la purificación del ácido nítrico, para que las aguas fuertes de los ensayes de oro no sean puras", a: Domingo García Fernández, Informes a S.M. Y RealJunta de Comercio, Moneda y Minas sobre algunas producciones naturales descubiertas en estos últimos...op.cit.

${ }^{25}$ J. Masdevall, Dictamen...op.cit, p. 9

${ }^{26}$ J. Masdevall, Dictamen...op.cit, p. 11

${ }^{27}$ Simon Tarres, A., El pensament demogràfic en època moderna, Curial, Barcelona, 1994
} 


\section{El debat Güell-Masdevall.}

El document de Masdevall és una resposta i una refutació, que generarà una revocació d'una prohibició que restringia el desenvolupament de la indústria i amenaçava en ralentitzar el seu progrés. Efectivament, tres mesos abans de la publicació del document, les autoritats municipals havien dictaminat la prohibició que noves fàbriques o tallers de llana i cotó s'establissin a l'interior de la ciutat, mesura que amb l'informe de Masdevall fou revocada.

El text ha estat interpretat com una defensa aferrissada de la indústria com a font de riquesa del país i com a mètode per a augmentar la població. Seguint Antoni Simon, el document legitima els seus arguments a partir de l'establiment de la penúria com a la veritable generadora de les malalties; el text es basa, doncs, en la relació carestia-penúria-malaltia, i defensa la indústria front l'agricultura com a motor del veritable progrés econòmic i social. Així, per exemple, el cas de Cervera en contraposició a la Plana d'Urgell és presentat per Masdevall com un exemple de com la penúria i la malaltia són causades per l'economia fonamentada només en l'agricultura.

El document és escrit en un moment clau per l'economia de Barcelona. Un moment marcat per l'acumulació de capital (acumulació que apuntalarà la indústria i finançarà l'inici del procés de mecanització). Aviat, l'acumulació que la manufactura requeria i impulsava, la mateixa divisió de les tasques i la ruptura amb les pautes d'organització dels antics oficis, prepararen i facilitaren la recepció d'una tecnificació del tintatge que en el moment de començar la Guerra del Francès ja anava prenent $\cos ^{28}$.

Així, el text de Masdevall, s'ha d'interpretar com un assumpte més polític que social, atenent la posició política de l'autor i la situació econòmica de Barcelona.

\footnotetext{
${ }^{28}$ Nadal, J.,"La indústria cotonera”, a Història Econòmica de la Catalunya Contemporània, Segle XIX, V.3, Enciclopèdia Catalana, 1991, pp. 184-185. Entorn el debat sobre la indústria catalana veure també: A.Sánchez, "La indústria catalana ¿Mito o realidad?", Revista de Història indústrial, no5, 1994, pp. 213-233; J.Nadal, "Sobre l'entitat de la indianeria barcelonina del set-cents", Recerques, 24, Barcelona, Curial, 1991, pp. 181-185, on l'autor proposa que en el darrer terç del segle XVIII és més factible parlar de manufactura del Illi, especialitzada en processos d'acabat que no pas d'indústria cotonera.
} 
Entorn del 1800, Barcelona era el nucli principal de la indústria cotonera i concentrava un terç dels treballadors d'aquest sector a Catalunya. La capital era el centre organitzador de les relacions comercials, receptor de la matèria primera i distribuïdor del producte acabat. Àdhuc, era un gran centre administratiu de serveis, en especial d'aquells relacionats amb la gestió dels intercanvis interns i externs de l'economia catalana. Segons Masdevall, Barcelona, en aquell moment, era el pal de paller del Principat, ja que la seva indústria estimulava el treball a tot el territori a través de la distribució del treball ${ }^{29}$.

Les contradiccions d'aquest desenvolupament, però, es fan explícites a la topografia mèdica de Güell. Una anàlisi dels problemes urbanístics de la ciutat, de l'existència d'adulteracions en aliments de consum, de la corrupció de l'atmosfera a conseqüència de les activitats econòmiques. Una anàlisi que recomanava explícitament que les noves fàbriques i tallers es traslladessin fora de la ciutat.

Alhora, el document denuncia les males condicions arquitectòniques de les fabriques i les males condicions d'un aire viciat a causa del gran número de persones que s'acumulaven a les fàbriques: "resulta un aire caliente, poco elástico, denso y cargado de vapores animales y exhalaciones nocibas que fatiga la respiración, relaja el cuerpo y le dispone a mil enfermedades crónicas y agudas que pueden muy fácilmente passar a ser epidemias" ${ }^{30}$. Unes circumstàncies generades per la mateixa organització del treball a les fàbriques, que obligava a una concentració del personal que feia molt insalubre el lloc.

\footnotetext{
29 Indubtablement, la indústria exercia un gran poder d'atracció de ma d'obra, segons Pierre Vilar aquesta atracció era el salari nominal. Aqeusta atracció provocava emigració del camp a la ciutat: "(...)los obreros encuentran todos mayor limpieza y comodidad en el laboreo del algodón. Abandonan por él hasta la misma agricultura, y, como no pide fuerza excesiva ni grande inteligencia el manejo de las indianas, todos se dedican a vivir de esta ligera ocupación (...)" (citat a J.Fontana, Cambio económico y actitudes políticas en la España del siglo XIX, Barcelona, Ariel, 1981); "Los matriculados (en la pesca) por ser tantos en número disminuyen el de los jornaleros que se necesitan para el cultivo de la tierra, los que suplen forasteros que vienen y son montañeses, gente poco aplicada al trabajo y por esto inclinadas a trabajar en las fábricaas de indianas y otros de la inmediación de esta capital y no lograndose remediar aquí la falta, se va despoblando la montaña en detrimento del estado" (declaracions del capellà de Badalona l'any 1789, citat a J.M. Cuyas, La Badalona del segle divuité, Badalona, 1936)

${ }^{30}$ Citat a López Ayala, B., Condiciones de trabajo en las fábricas de indianas de Barcelona durante el último tercio del siglo XVIII, "Manuscrits", nํ․, 1987, pp. 126-127.
} 
En efecte, segons un document de la Junta de Comerç de Barcelona, en una fàbrica d'indianes hi trobàvem fins a divuit categories diferents ${ }^{31}$ : fabricant, majordom dels teixidors, encarregat de les peces i de la venda, ordidors, teixidors, dones i nenes debanadores, gravadors, dibuixants, estampadors, nois per ajudar als pintadors, peons, brunyidor, encebador, nois per ajudar al brunyidor, majordom del prat, peons del prat, nois del prat i conductors de carro. Una organització que sembla confirmar la idea de treballador exposada per Lewis Mumford ${ }^{32}$. Per aquest, el treballador no és més que un engranatge més de la fàbrica. En efecte, Lewis Mumford explica la cultura industrial a partir del concepte de la "megamachine". Per aquest autor, un treballador és un engranatge més d'aquesta mega màquina que, alhora, el degrada completament. El degrada perquè, per Mumford, el sistema industrial és equivalent a la disciplina de la misèria, és la castració de la perícia artesana tradicional dels gremis, condueix a la sobrevaloració del treball, a l'adulteració de la vida, a la pèrdua de llum, a la degradació de la sensualitat, al tancament de tota ocupació alternativa mitjançant el monopoli de la terra, i a la des-educació ${ }^{33}$.

Així, doncs, les fàbriques d'indianes ho eren en el sentit actual de la paraula: s'organitzaven seguint el model manufacturer, concentraven les diferents fases del procés de producció en un mateix recinte, agrupaven els treballadors per reforçar el control, accentuar la divisió de les tasques i millorar-ne la coordinació ${ }^{34}$. Unes circumstàncies que mostren que la tecnologia no és neutral. La centralització de la producció és bona pels industrials, però els problemes concomitants pels treballadors són evidents. Un cas paral-lel a l'analitzat per Reynolds i Cutcliffe ${ }^{35}$ pel territori britànic abans del 1800.

La Junta de Sanitat de Barcelona, després que l'Ajuntament revoqués la prohibició d'establir més indústries dins de Barcelona, no prengué més mesures, tot i que les denúncies ciutadanes sobre el perjudici d'aquestes eren molt

\footnotetext{
${ }^{31}$ Biblioteca de Catalunya, Junta de Comerç, lligall 53, caixa 71, núm 25

${ }^{32}$ Mumford, L., Técnica y civilización, Madrid, Alianza, 1974

${ }^{33}$ Mumford, L., Técnica y...op.cit., p.192.

${ }^{34}$ Història Econòmica de la Catalunya Contemporània..., op.cit, vol I, p. 32

${ }^{35}$ Reynolds, T. S., i Cutchiffe, S. H., Technology in the Preindustrial West, p. 35.
} 
abundants. Aquest fet és explicable si tenim en compte la gran incidència del corrent de pensament il-lustrat i el seu pes sobre les decisions de caire polític, social i econòmic. Endemés, les fàbriques contribuïen a estimular la demanda d'altres productes en benefici de la hisenda reial. Productes com l'alcohol. En efecte, segons el vuitè punt d'un informe de 1784 de la Junta de Comerç -referent a l'estat de les fàbriques d'indianes- presentat pels directors de la companyia de filats de cotó: "(...)por mucho que reduzcamos el cálculo de los consumos de nuestros operarios dentro de esta ciudad, excederá de media mitad de ella al día por cabeza, a cuyo respecto este ramo contribuye en la actualidad a la real hacienda de cuatrocientos mil reales de vellón. Texedores y pintadores tienen hijos a los que suministran este licor, bien que parcamente $y$ esto es otro aumento del producto de aquel derecho,36.

En aquest context s'ha d'entendre la postura de Masdevall, que es pot definir com a representant paradigmàtic de l'ideari oficial del despotisme il-lustrat que anteposava el creixement de la població i la riquesa del país ${ }^{37}$. I, en aquest sentit, cal interpretar una carta al comte de Floridablanca del 7 de setembre de 1784, on Masdevall carregava contra els contraris a les fàbriques, titllant-los d'ignorants: “(...) y en realidad hablando como debo a V.E. con la más grande ingenuidad se me parte el corazón de dolor de ver que los más de ellos son los más ignorantes médicos de la provincia, y si fueran otros tal vez no hubiera visto aquella Ciudad en sus esquinas los edictos contra las fàbricas de algodón y lana, $y$ estoy bien persuadido que su población fuera aún mayor de la que es actualmente, ${ }^{38}$.

\section{Carbó mineral i manca de fusta.}

L'altra material conflictiu des del punt de vista mediambiental fou el carbó mineral i el seu ús com a combustible. El seu estudi s'engloba dins les anàlisis

\footnotetext{
${ }^{36}$ Biblioteca de Catalunya, Junta de Comerç, lligall 53, caixa 71, № 29, 15 de desembre de 1784

${ }^{37}$ Riera, J., José Masdevall y la medicina española ilustrada, Valladolid, 1980

${ }^{38}$ Carta reproduïda per J.Riera, José Masdevalll...op cit. p. 176-180
} 
dels sistemes energètics proposats per físics com Paul Deléage ${ }^{39}$. Segons aquest, el concepte de sistema d'energia es defineix tant per les característiques ecològiques i tecnològiques de les cadenes de convertidors energètics com per les estructures socials d'apropiació i de gestió de les fonts d'energia i els mateixos convertidors. El sistema energètic així entès és, doncs, la combinació de diverses cadenes energètiques en el si d'una societat que controla i distribueix aquests recursos.

Seguint la classificació de Mumford, el pas de l'etapa històrica eutèctica a la paletècnica el trobem amb la substitució del carbó vegetal pel mineral. Aquesta substitució palesa que la intensitat de l'ús de qualsevol combustible és un procés paral-lel a les pulsacions econòmiques. Una idea que ja se suggerí, pel cas britànic, en el clàssic article de Te Brake ${ }^{40}$. En aquest, l'autor exposa com els ritmes de la contaminació responen als cicles demogràfics. Aquests, determinen la demanda de calefacció i, consegüentment, la demanda d'una fusta cada cop més escassa que té com a alternativa més "ecològica" el sea coal ${ }^{41}$. Segons Te Brake, a la ciutat de Londres, ja des del 1257, apareixen queixes per la inhalació del sea coal, per I'"smoke nuisance" que aquest provoca. El problema augmentà amb l'increment de la població i la demanda de carbó a la capital i a altres zones, fins el punt que Eduard I imposà penes a qui l'utilitzés. En el moment que a Anglaterra el problema sembla irresoluble, paradoxalment, se "soluciona" amb la pesta negra i la caiguda de població. Un problema, però, que ressorgirà a partir del 1600 a causa de l'augment de la població.

A Anglaterra, el debat que apareix vers 1600 gira entorn a dues alternatives: sacrificar els boscos i evitar la contaminació del sea coal, o bé utilitzar el sea coal i recuperar els boscos. Un debat que integra les dues perspectives destacades per

\footnotetext{
39 Deléage, Jean Paul, Historia de la Ecología, ICARIA, Barcelona, 1993. Història i Ecologia, Recerques, 26, Curial, Barcelona, 1992.

40 William H. Te Brake, "Air, Pollution and Fuel Crisis in Preindustrial London, 1250-1650", Technology and Culture, 16, no3 (juliol 1975), 337-59.

${ }^{41}$ Brimblecombe, P., "Attitudes and Responses towards Air Pollution in Medieval England", Journal of the Air Pollution control Association, 26, no10, (octubre 1976), 941-45; i per la industria del carbó a Anglaterra: John U. Nef, The Rise of the British Coal Industry, 2 vols. (London, 1932).
} 
Bevilacqua l'any 1993 referent a què és la història ecològica: la història de les contaminacions i la història dels recursos naturals ${ }^{42}$.

Precisament, el benefici que comporta la recuperació dels boscos és un dels arguments més emprats dins del discurs generat entorn la conveniència de la introducció del carbó mineral en la Barcelona de finals del XVIII -tal i com mostra l'obra de 1786 del naturalista Josep Comes ${ }^{43}$, autor de l'obra Memoria sobre el carbón de piedra para persuadir y facilitar su uso en Catalunya $(1786)^{44}$. En efecte, Comes elogia a bastament a Anglaterra pel fet que, a través de l'ús del sea coal, aquest país ha aconseguit evitar la pèrdua dels seus boscos.

A Catalunya, l'intent d'introduir el carbó mineral segueix clarament les pulsacions econòmiques i demogràfiques catalanes. La introducció fou precipitada, bàsicament, per tres raons. En primer lloc, per l'escassetat de fusta als boscos propers a Barcelona -per l'extensió de la vinya. En segon lloc, pel seu alt preu -per aquesta època, Vilar $^{45}$ constatà en un $300 \%$ l'augment del preu de la fusta entre 1740 i els anys finals del segle XVIII, el que interpretà com un clar indicador del desboscament. I, en tercer lloc, per les males condicions d'una xarxa de transports que impossibilitava d'arribar a les muntanyes més llunyanes. A més cal inscriure l'època moderna un període de guerres continuades des del segle XVI i que enllacen amb l'augment de les roturacions per l'ampliació dels cultius en el segle XVIII. Ens trobem, doncs, amb una etapa de continuades tales, incendis, arrasaments de terra, etc. actituds que comportaren clares pertorbacions del medi.

Fou l'any 1785 quan el Síndic Personero exposà per primer cop que la manca de carbó provenia del creixent consum de llenya per part de les fàbriques de Barcelona i la resta del Principat i per la pressió demogràfica arreu del Principat -que havia provocat la reducció d'uns boscos substituïts per cultius i vinyes i, alhora, havia augmentat la demanda de material de construcció. Per l'Audiència, la

\footnotetext{
42 Bevilacqua, P., "Las políticas ambientales: ¿qué pasado? Algunas reflexiones", Historia y Ecología, Madrid, Ayer, 1993.

${ }^{43}$ Membre de la Conferència Física (1769) i de l'Acadèmia de Ciències i Arts.

${ }^{44}$ Comes, J., Memoria sobre el carbón de piedra para persuadir y facilitar su uso en Catalunya, Barcelona, 1786.

Barcelona, Impresor Surià y Burgada

${ }^{45}$ Vilar, P., Catalunya dins l'Espanya moderna, vol III, pp. 235-243.
} 
solució per evitar la pèrdua total dels boscos era el carbó mineral: "el uso de este carbón ahorrará en gran parte el consumo del de madera, cuya economia es util y necesaria" ${ }^{46}$.

La resposta dels Almotacenes, Síndics i diputats de l'Ajuntament fou la negació de l'escassetat de fusta. Una idea sustentada amb l'argument que la llenya només escassejava en els punts pròxims a Barcelona, però no a l'alta muntanya; puix que el problema es produïa per la manca de transports capaços d'arribar a les zones amb boscos.

Al segle XVIII, l'escassetat de fusta i de carbó vegetal també genera plantejaments de gestió dels boscos per part dels il.lustrats. Uns, fan un discurs pessimista i destaquen com l'impacte humà sobre els boscos genera efectes perniciosos i degrada la massa forestal; amb les conseqüents externalitats negatives com el desbordament dels rius. Un discurs que evidencia la progressiva presa de consciència il.lustrada respecte el paper que duen a terme les masses forestals dins de l'equilibri ambiental. Aquests plantejaments el recuperaran els metges del XIX, tal i com exposa Urteaga ${ }^{47}$, amb l'objectiu d'elaborar aquell discurs que relaciona salut i existència de masses forestals.

D'altres il.lustrats, empren aquesta visió carregada de pessimisme per legitimar la necessitat de la gestió del bosc, perquè aquest sigui capaç de suplir les necessitats de la Marina Reial. Uns plantejaments il.lustrats paral.lels als suggerits per Grove als tròpics ${ }^{48}$; i precedents del debat desenvolupat a Amèrica entre les idees de Pynchort ${ }^{49} i$ les de Muir $(1838-1914)^{50}$. El discurs de Pynchort, enginyer forestal, és un intent d'aplicar els elements tayloristes per trobar criteris de conservació dels recursos naturals a través d'una nova ciència capaç d'organitzar els recursos naturals: el Scientific Management. D'altra banda, per

\footnotetext{
${ }^{46} \mathrm{BC}$, Acuerdos, libro núm. 8, p. 385

47 Urteaga, L., "Higienismo y ambientalismo en la medicina decimonónica", Dynamis, 1985-6, pp. 417-425.

${ }^{48}$ Bonneuil, op.cit. p. 78.

${ }^{49}$ Hays, S. P., "Gifford Pynchot and the American Conservation Movement",

${ }^{50}$ Biografies o estudis crítics de Muir: Wolfe, L. M., Son of the Wilderness: The Life of John Muir, 1945; Fox, S., John Muir and His Legacy: The American Conservation Movement, 1981; Cohen, M. P., the Pathless Way: John Muir and American Wilderness, 1984; Turner, F. W., Rediscovering America: John Muir in His Time and Ours, 1985.
} 
Muir la natura havia de ser protegida i preservada en el seu estat originari. Un debat generat paral-lelament als estudis de la història de la frontera, considerada, per molts, com el bressol de la història ecològica.

\section{Introducció carbó mineral. Dialèctica i reacció mèdica.}

La introducció del nou combustible a Catalunya té com a punt de referència el progrés econòmic europeu; com a precipitant, la crisi de finals del XVIII, la crisi de combustibles i la necessitat d'impulsar les industries; i com a element legitimador, la ciència mèdica de la salut pública, recolzada en els avenços químics del moment i el progressiu enteniment de la composició de l'aire.

La dialèctica sorgida arrel la introducció del carbó i dels tints presenta una estructura trífida: política, econòmica i social. La política es genera entre l'Ajuntament i l'Audiència; la social entre els industrials i els veïns; i l'econòmica amb els treballadors del carbó vegetal.

La dialèctica entre l'Ajuntament i l'Audiència es genera per la moderació de la primera, front el discurs progressista de la segona. Unes diferències que ens parlen dels interessos implícits a qui servia cada institució. La primera a les classes propietàries tradicionals i la segona a la nova burgesia ascendent. És significatiu com defineix l'Audiència les reticències de l'Ajuntament: "como qualquier novedad aunque tenga maiores ventajas siempre encuentra obstáculos insuperables con pretextos equivodados y discursos fanáticos, parto infeliz de la ignorancia, si no logra el Patrimonio de un poderoso, bajo cuya segura sombra medie en sus principios hasta dejar disipada la niebla de la preucupación"151.

La dialèctica entre les fàbriques i els veïns és evidenciada per les propostes de solucions institucionals, mèdiques i científiques per resoldre les molèsties ocasionades pel fum del carbó. Uns documents que semblen fer-se per desmuntar la teoria estesa entre l'opinió pública segons la qual els països que empren aquest combustible són insans. En efecte, els informes mèdics i les obres referents al carbó s'esforcen a negar, reiteradament, que les malalties nord europees siguin

\footnotetext{
${ }^{51}$ AHB, Polític, Reial i Decrets, 1782
} 
causades pel fum del carbó mineral. Una argumentació que els metges catalans legitimen a través dels resultats de les anàlisis químiques de l'aire sotmès a la combustió del carbó mineral. Així, els documents tot sovint adopten la postura de la previsió i denoten la voluntat de calmar a uns ciutadans i a unes institucions alarmats pel que podria passar vista l'experiència britànica. A aquest objectiu responen els informes de la Junta de Sanitat -fets a requeriment governatiu-, les anàlisis científiques de la Conferència de química des de 1769 i de la Secció de Química de la Reial Acadèmia de Ciències i Arts des de 1785, i les monografies dedicades al tema com l'obra del metge Josep Comes ${ }^{52}$.

Les referències identificades que evidencien problemes de salut a causa del carbó mineral són dues: una és la referència indirecta citada en un document de l'Audiència referent a l'ús del carbó sense tractament purificador; i, l'altra, és una queixa de 1790 formulada pel convent dels Dominics contra una fàbrica de vidre que utilitzava carbó mineral.

Cal citar també, a banda de les referències als problemes urbans, la presència en els documents del tema de les condicions dels treballadors de les mines. En efecte, el cas dels problemes de salut en l'àmbit laboral són analitzats per Comes $^{53}$, qui reconeix que el moment més conflictiu sanitàriament parlant és el moment de l'extracció del mineral en les mines. Així, exposa recomanacions mèdiques i tècniques per tal d'evitar perjudicis pels treballadors de les mines, idees que basa en les obres de Henckel, Triewald i Hellot ${ }^{54}$.

Una preocupació que podríem emmarcar en les idees que es consideren els precedents de la literatura higienista del segle XIX dedicada exclusivament a les dolences professionals ${ }^{55}$. Un precedent, recordem, emmarcat en un moment d'emergència de la salut pública basada en la ideologia il-lustrada que, seguint Jordanova $^{56}$, a partir de la segona meitat del XVIII és un concepte que defineix el control de la pràctica mèdica per part de les institucions.

\footnotetext{
${ }^{52}$ Comes, J., Memoria sobre el carbón de piedra...op.cit, pp. 50-60

${ }^{53}$ Comes, J., Memoria sobre el carbón de piedra...op.cit, pp. 54

${ }^{54}$ Memories de l'Academie des Sciences de Paris, 1735, pp. 22.

${ }^{55}$ Urteaga, L., "Higienismo y ambientalismo...op.cit, p. 422

56 Jordanova, L.J., "Policing Public Health in France 1780-1815..., op.cit.
} 
Al segle $X V I I I$, tot i que manca un moviment social generalitzat de control del fum a Barcelona, trobem intents de solució basats en la purificació del fum del carbó feta a través d'operacions químiques. Així, l'any 1785 davant el fet de la venda il.legal de carbó mineral provinent d'Anglaterra al Port de Barcelona, l'Audiència alerta que aquest es consumeix sense precaució i sense el tractament necessari que indiquen els científics -la purificació-, i ocasiona, així, una pudor inaguantable; per la qual cosa adverteix que pot ocasionar efectes contraris a la Salut Pública. Apel-lant a la salut pública, l'objectiu de l'Audiència és convèncer a l'Ajuntament de la llibertat d'ús del carbó mineral, per evitar així la seva venda i distribució sense regulació ${ }^{57}$.

El mateix any les institucions reiteren la necessitat d'evitar els problemes del fum. Així, el 9 d'abril de 1785, la Junta de Sanitat de l'Ajuntament, concretament els metges Esteve, Balmes i Prat, demanen una anàlisi química a la Reial Acadèmia que analitzi el carbó de pedra -als químics Mollar i Francesc Sala-; amb l'objectiu que l'Audiència pugui dictaminar si el seu ús és o no és nociu per la salut pública ${ }^{58}$. El dictamen serà clarament favorable a l'ús del carbó mineral.

En l'informe ${ }^{59}$, els químics descriuen el procés d'anàlisi química -destil-lació (al forn) per obtindre els diferents components: liquor aqueo, aceyte, i el residu; i, en segon lloc, tractament amb la Màquina Pneumàtico-Química, per recollir-ne els gasos. La Junta de Sanitat analitza l'informe dels químics Mollar (considerat com un dels introductors dels nous conceptes de la química moderna a la Reial Acadèmia) i Sala, i conclou que la tasca dels químics ha estat insatisfactòria per no aportar res de nou als seus coneixements. "no quedamos nosotros satisfechos por dichos análisis(...)se infiere que la análisis es enteramente superflua, y en adelante pasemos sin esta parte de la química".

Segons la Junta de Sanitat, l'informe no aconsegueix analitzar les especificitats del carbó mineral d'Isona, donat que es limita a dir els components

\footnotetext{
${ }^{57}$ Finalment, el lliure comerç serà otorgat per Real Cèdula el 1792 BUB, fons antic, 87-3-20-42; en un document que palesa el desig de la Corona de promoure el progrés de les industries i, alhora, palesa la prevenció de la Marina per tenir el control del material -tal i com abans s'encarregà de tenir-lo sobre els boscos i l'extracció de fusta.

${ }^{58}$ AHB, Polític, Reial i Representacions, 1785
} 
del carbó sense indicar les proporcions exactes del carbó català. D'aquesta manera, els metges de la Junta prefereixen deixar de banda l'anàlisi química i extreure les conclusions dels seus propis coneixements, forjats a partir de l'obra de Hoffman (1660-1742) ${ }^{60}$, Macquer, Valerius i Moranet. Aquests, segons el Síndic, declaren que l'ús no és perjudicial i, tot i que la manca de costum pot causar molèsties, el mateix costum les farà desaparèixer.

Aquests metges referenciats basaven la seva pràctica mèdica en la terapèutica química $i$, alhora, la seva citació als textos catalans ens podria proporcionar dades sobre la recepció de les teories de la combustió. Els estudis sobre la composició de l'aire i l'aigua de Macquer, per exemple, facilitaren la tasca de Lavoissier, tot i que mantingué, contra les idees d'aquest, la teoria del flogist. De fet es considera el darrer defensor de la teoria del flogist a França. La seva presència als textos catalans, doncs, potser ens podria dir molt de la recepció de les teories químiques de l'època.

Finalment, a partir dels informes químics i mèdics, el síndic elaborarà un dictamen datat el 27 d'abril de 1785. En aquest, exposa la conveniència que, en un principi, es permeti el seu ús a les cases de camp i a les fàbriques de fora de la ciutat -prèvia purificació. Concloent que, a partir de les observacions de l'ús a aquestes zones, es podria avaluar la seva influència sobre la salut. Així, l'experiència permetria elaborar informes en un futur i ponderar amb més coneixement de causa la conveniència del seu ús a l'interior de la ciutat.

El tema de la necessitat de purificar el carbó és tractat a bastament per Comes $^{61}$, que es basa en els treballs i mètodes de Joubert; que tenien l'objectiu de treure la mala olor del carbó a través de l'evaporació de les parts volàtils. Segons el Síndic, a aquest carbó els anglesos l'anomenen coach, i és el més adequat per utilitzar en els brasers i habitacions interiors. I és aquest tipus l'únic que cal deixar entrar a la ciutat. Significativament, Comes cita com a exemple de bon ús del carbó els països que ja l'usen, especialment Anglaterra. D'allà destaca, per una

\footnotetext{
${ }^{59}$ AHB, Polític, Reial i Deliberacions, 1785

60 Medicina rationalis systematica; Medicina consultoria (Halle, 1721-39); Theoremata physica (Halle, 1694); Fundamenta medicinae (Halle, 1696).
} 
banda, que ha sabut evitar la destrucció dels boscos; i, per l'altra, que l'ús del carbó no ha estat perjudicial, malgrat el discurs creat en contra seu per part de l'opinió pública; opinió pública que ha estès la idea que el carbó és la causa de la consomption. Segons Comes, la causa de la consomption no és el carbó sinó el licor.

Així, doncs, tant per les institucions, com pels químics i pels metges, el carbó mineral no només no és perjudicial sinó que, al contrari, és beneficiós per la salut $i$, fins i tot, molt més recomanable que el vegetal. Puix que, seguint Comes, el carbó mineral pot acabar amb la pesta, amb les morts sobtades i, alhora, pot actuar com a correctiu de les exhalacions pútrides orgàniques. Una opinió constatada a través de les anàlisis químiques de Mollar i Sala: "es uno de los medios para purificar el aire en tiempo de peste, y por lo mismo que purifica el aire no seria impropio decir que de esta ciudad minoraría las muchas aplopegías que se experimentan". Una idea que Comes legitima a través de les dissertacions mèdiques i químiques d'autors com Walerio, Hoffman i Morand (assessor honorari del Col-legi de Metges de Lieja), en els informes favorables al carbó mineral de les Reials Acadèmies de París, Lovaino, Lieja, Lyon, València i Londres, i en la bona salubritat de ciutats que usen carbó mineral com Alemanya, Escòcia, França i Anglaterra.

A finals del set-cents, el problema del fum tornarà a aparèixer a través de les denuncies contra les fàbriques de vidre. Un problema que rep unes respostes institucionals que mostren que l'interès econòmic preval al sanitari. A la dècada dels noranta, el problema del carbó mineral sobre la salut es palesarà a les fàbriques de vidre per les nombroses queixes dels ciutadans, entre ells el Rector del Col-legi dels Dominics. L'any 1796, l'Audiència demanà un informe a I'Ajuntament sobre la fàbrica de vidre d'en Ignasi March. L'Ajuntament respongué que els metges, a la dècada anterior, tot i que indicaven que el carbó mineral no era perjudicial, recomanen que era convenient que les fàbriques es traslladessin on no fos perjudicial pels veïns. Malgrat l'informe, les pressions del Corregidor,

${ }^{61}$ Comes, J., Memoria sobre el carbón de piedra...op.cit 
perquè es mantingués la fàbrica, al-legant els beneficis econòmics d'aquesta, van provocar que restés dins la ciutat. Així, l'Audiència dictaminà que donat que, d'una banda, la fàbrica no causava cap problema per la salut pública i, d'altra, els perjudicis ocasionats als amos amb un possible trasllat eren molt grans, els dos factors eren raons més que suficients per desestimar les queixes del col-legi de dominics i dels veïns que es queixaven: "pues el beneficio público debe ceder al particular y sufrir por aquél una leve molestia, que es lo más que puede producir...". La dialèctica entre els diferents grups socials evidencia la veracitat del discurs de Kranzberg referent al fet que la tecnologia és depenent de les forces externes als emissors o receptors -circumstancies socials, econòmiques, polítiques o culturals-.

\section{Conclusions.}

Al segle XIX, el discurs mèdic no es basarà tant sols en la legitimació dels elements perjudicials sinó que les anàlisis sobre les relacions entre el fum i la vida dels treballadors o veïns es faran més crítiques i més generalitzades. Es passa de la valoració de la industria i la sensibilitat social i humana de la il-lustració a les posicions pròpies del romanticisme; quan ja no s'ocultaren les dures circumstàncies dels obrers ni els problemes reals que ocasiona el fum.

La crítica al fum, però, prové de grups que temem pel futur imperial, social i econòmic del seu país. Responen, doncs, a la ideologia higienista, segons la qual calia millorar la salut de les classes treballadores com un mitjà per recuperar l'eficàcia de la mà d'obra productiva, reduir la conflictivitat social i protegir la salut de la resta de la població. Així ho palesen els Smoke Abatemen Groups que proliferen a Gran Bretanya i Estats Units durant el vuit-cents; uns grups treballats per autors com Stradling i Thorsheim ${ }^{62}$. Per aquests grups, el fum, i no pas l'ús del carbó, és emprat com a símbol d'un conjunt de problemes que poden derivar en la inestabilitat social. I és aquesta por la que genera els discursos que clamen per la necessitat de solucions. Un discurs, però, que evidencia que durant tot el segle 
XIX -com ja s'apunta a finals del segle XVIII- el desenvolupament industrial és prioritat.

El recel de l'Ajuntament a les innovacions cal entendre'l dins la lògica mèdica i social del moment. La reticència es basa en el temor a la inestabilitat social que podria conduir la destrucció de tot un sistema social i econòmic basat en l'economia del carbó de fusta; per altra banda, cal tenir en compte la precaució davant la possible empitjorament de la salut dels treballadors, la base de l'economia del moment, i dels veïns, amb les conseqüents disturbis socials que el tema provocaria.

Des de la història ecològica s'entén que reconèixer com a moviments ecologistes només aquells sorgits durant els seixanta o setanta és una simplificació. Es reconeix, evidentment, que als anys seixanta es produí l'adveniment de l'ecologisme que ha marcat el segle XX; un moviment que obeeix a la lògica econòmica i social d'aquest segle. La història ecològica, però, advoca que la recerca tingui un perllongament cronològic vers el passat per tal de trobar el caràcter mediambiental dels moviments reformistes socials i dels moviments reticents a les noves tecnologies que al llarg de tota la història han intentat evitar un possible empitjorament de la vida de les classes treballadores o la destrucció de les seves bases socials.

En aquest sentit, els treballs de Mumford posen en dubte la imatge que entén els moviments reticents a les innovacions industrials -en el cas de Barcelona l'Ajuntament, els veïns, i les economies basades en el carbó vegetal- com a immobilistes i endarrerits. Mumford, així, estimula aquells treballs que estudien la racionalitat de la reticència, treballs com els de Bruland ${ }^{63}$, referents a l'energia nuclear, la fusta o la pesca-, o la reinterpretació del ludisme de l'etapa 1790-1800 feta per Randall ${ }^{64}$.

\footnotetext{
62 Stradling, D., i Thorsheim, P., "The Smoke of Great Cities. British and American Efforts to Control Air Pollution, 1860-1914", Environmental History, 1999, pp. 6-31.

63 Bruland, K., "Patterns of resistence to new technologies in Scandinavia: an historical perspective", dins Bauer, M., Resistance to new technology, Cambridge, Cambridge University Press, 1998

64 Randall, "Reinterpreting 'Luddism': resistance to new technology in the British Industrial Revolution"
} 
